\title{
Chapter 4. Rank, Hierarchy and Routes of Migration: Chieftainship in the Central Caroline Islands of Micronesia
}

\section{Ken-ichi Sudo}

\section{Introduction}

The traditional political communities of the central Caroline Islands, from Ulithi to Namonuito Atoll, are characteristically small. A politically autonomous community may consist of a single village, a district or a small island, each composed of matrilineal descent groups. The total population of an island or an atoll is, on average, less than 800 persons and its land area is at most five square kilometres in extent. Some scholars have suggested that institutionalized chieftainship in Micronesia, as a form of suprafamilial authority, is directly related to surplus food production (e.g. Mason 1968). Therefore, due to their meagre resource base, the societies of the central Carolines should necessarily be unstratified and egalitarian.

This, however, is not the case. Instead, these polities are characterized by hereditary chieftainship and ranked kin groups. Shimizu (1987) classifies the polities of the Carolines and the Marshalls into two main types:

- chieftainships of a primus inter pares type, as in Palau (Belau) and Yap,

- centralized chieftainships, as in the central Carolines, Truk, Pohnpei, Kosrae, and in the Marshalls.

He concludes that political organization in Micronesia shows little correlation with environmental conditions (Shimizu 1987:249).

The matri-clans or matri-lineages of the central Carolines are divided between those of chiefly and non-chiefly rank. Rank is related to the sequence of a clan's or lineage's arrival on an island or in a particular locality (Alkire 1978:117, 1984:6-7). Claims to priority of settlement are generally asserted in terms of oral histories of migration routes and land ownership. In this regard, there exist two "contradictory" narrative traditions concerning the homeland of ancestral migrants to the central Caroline Islands. One is a narrative tradition that links migration to an "eastern route", from "Kachaw". The other link is to a "western route", from the "Yap Empire". 
Origins, Ancestry and Alliance

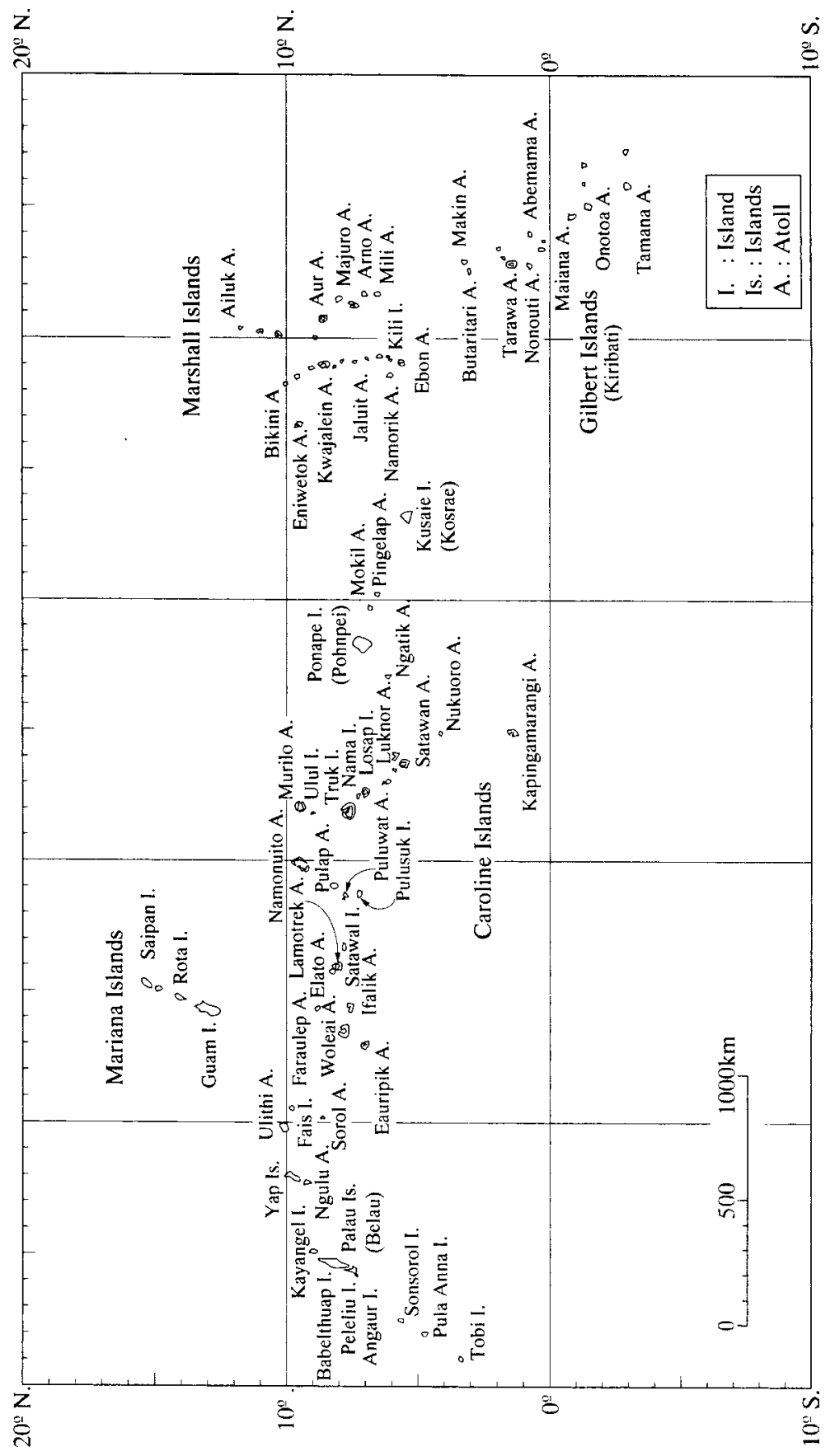

Map 1. The Micronesia Islands.

The aim of this paper is to examine the oral historical traditions that relate to rank among kin groups and islands and to clarify, more specifically, the nature 
of chieftainship on Satawal Island. I describe mainly the way in which oral traditions of migration help create social rank and legitimize chieftainship according to notions of political precedence among islands and kin groups.

\section{Socio-Political Organization}

Satawal is a raised coral island with an area of one square kilometre. It lies 1,000 $\mathrm{km}$ east of Yap and $500 \mathrm{~km}$ west of Truk (Map 1). The principal kin group and unit of landholding on the island is the matrilineal clan (yáyinang) or lineage (yeew raa, lit., "one branch of the tree"). The members of a yáyinang do not necessarily live only on Satawal; they may also live on other islands. Of those who live on other islands, some are able to trace their genealogical connections to known ancestors, while others simply identify themselves with the name of a particular clan. Clan members are obliged to assist one another and are prohibited from marrying. Residence is matri-uxorilocal and the residential group consists of a matri-extended family. Family members live in adjacent houses built on lineage land and form a corporate, co-residential group called a pwukos or homestead. In 1980 there were 15 homesteads on Satawal Island, the largest of which contained 12 households with a total of 71 members (Sudo 1984, 1989).

Satawalese society is comprised of eight matri-clans, each of which is ranked. Clan genealogies can in some instances be traced back eight generations. All clans are conceptually ranked in terms of their arrival on the island. Their rank order is as follows: Neyáár, Yáánatiw, Noosomwar, Sawsát, Kataman, Piik, Sawen, and Maasané. The three highest-ranking clans are known as the "first settlers" and are referred to as "chief clans". The others, except Sawsát, are considered to be later immigrants and are referred to as "commoner clans". Although the Sawsát clan is classified as a commoner clan, its ancestors are said to have come first to the island, before the arrival of the ancestors of the other clans.

The genealogically senior and oldest male of the senior lineage in each clan serves as the clan head. The heads of the three chiefly clans are called "the chiefs of the island" and have authority to initiate and organize island and inter-island activities. The three chiefs and the head of the Sawsát clan make up the chiefs' council. The council discusses important affairs of the island, such as communal fishing, ocean-going expeditions by canoe, sanctions imposed on individuals, and various matters transmitted from the state government. After decisions are reached by consensus, the council calls an island-wide meeting at which these decisions are announced. This meeting is open to all the adult men of the island. At it, members of the chiefly clans and the heads of the commoner clans have the right to speak, while ordinary members of commoner clans are barred from speaking unless asked to by the others. 
The three chiefs are also responsible for controlling food resources. For example, in times of scarcity, they may place a taboo on the use of taro patches and coconut palms that are owned by individual lineages, or taboo the use of particular areas of sea. They also have superior authority in maintaining social order and act as mediators or judges, settling conflicts between clans, such as disputes over land boundaries or adultery compensation. Chiefs are therefore expected to be knowledgeable concerning custom, land tenure, genealogies, and command such esoteric knowledge as navigation techniques, divination, and weather forecasting.

The three chiefs are status-ranked; the highest is the chief of Neyáar, the second is the chief of Yáanatiw, and third is the chief of Noosomwar. The chief of the Neyáár clan is entitled to receive tribute of the first breadfruit and the first coconut palm toddy from every household on the island, according to the seasonal calendar. The chief selects his own food and immediately re-distributes the rest to all of the other homesteads. These prestations are considered a token payment of honour to the chief as head of the "first settlers' clan" and as acting agent for controlling the fertility of crops. Before Christianity was adopted in 1953 the chief had power over crops. The chief of the Neyáar clan directed a diviner to foretell the success or failure of the new year's crops and to perform rituals of fertility. Today this tribute is ceremonial rather than substantial. On the other hand, the head of the Sawsát clan has exclusive right to butcher all sea turtles and distribute their meat. As a ceremonial token, the head of the turtle is considered a gift to the Sawsát clan, as the "original immigrants" to the island (Sudo 1985).

The stratified status of chiefly and commoner clans is further supported by oral history and differences in landowning.

\section{Oral History of Satawal: Chiefly and Commoner Clans}

The oral history of the central Carolines traces what are claimed to be the indigenous migration routes and the order of settlement of the islands. This history is called rapito or wuruwow, "original story to come" or "legend", and is preserved as secret knowledge by individual clans. This history is viewed as a central determinant of clan rank. Let me summarize three migration stories from Satawal.

The original settlers of the island are recognized as the ancestors of the Sawsát clan, which means "proprietors of the sea" or "lords of Satawal". The Sawsát clan's oral history is told as follows.

Long, long ago, warfare on Yarawo (or Kachaw) island, caused by overpopulation and a shortage of food, led the ancestors of the Sawsát clan to leave the island in rafts. They drifted to Truk and then to Puluwat Atoll. Finally four men and seven women arrived at Satawal and settled 
on the western coast of the island near the entrance to its lagoon. After a time they decided to invite people from other islands to join them at Satawal, since the island was otherwise uninhabited at the time. Some voyaged to Lamotrek Atoll. There they learned that Lamotrek was a "chiefly island", controlling Satawal and the Elato Atoll.

Accepting the invitation of the Sawsát clan, some Lamotrekan people of the Yatonoyong clan moved to Satawal. The Sawsát people gave them a large parcel of land covering the southern part of the island and directed them to settle there. The chief of the Sawsát clan married a woman of Yatonoyong who bore a son. The chief transferred authority over the island to his son since the latter was obedient and looked after his father and the other members of his father's clan. In return, the Sawsát clan became subordinate to the Yatonoyong clan (Sudo 1985:640-642). After this transfer of authority the Yatonoyong clan changed its name to Neyáár, because its members lived at the time under a yáár tree.

According to the traditions of Neyáár, which thereby became the chiefly clan of first rank, its clan ancestors are said to have come to Satawal from Yarawo via Ifalik and Lamotrek. After this, some people of the Mongonufarh clan came to Satawal from Lamotrek. The head of the Neyáár clan directed them to settle the northern part of the island. This group was called "Yáanatiw" and was named for the area they settled. Thirdly, another group from the Mongonufarh clan on Lamotrek migrated to the island and settled in the middle of Satawal island under the direction of the Neyáár clan. This group was called "Noosomwar" (lit., "not moving anywhere").

The oral history of Yáanatiw and Noosomwar, both of which were originally from the same Mongonufarh clan, indicates that their home island was Ifalik Atoll situated to the west of Lamotrek. Their ancestors also left Yarawo and drifted to Yap or Ifalik. On Ifalik three girls were born and placed in cradles hung under a three-pronged branch (mong) of a pandanus tree (farh). Although one of them stayed on the island, the other two girls were taken respectively to Woleal and Lamotrek by the people of Ifalik. They married and had children on each island. Their matrilineal descendants were called "Mongonufarh". Some members of the Mongonufarh clan of Woleal later came to Lamotrek where they founded a separate "clan" distinct from the other Mongonufarh clan. These two branches of the Mongonufarh clan are called Yáanatiw and Noosomwar on Satawal. They are considered independent "clans" and their members are allowed to inter-marry.

After these four clans had settled on the island, seven clans are said to have come to Satawal from the eastern islands, such as Truk, Tamatam, Puluwat, or Pulusuk. Today representatives of only four of these clans remain on the island. 
Each was given plots of land on which to settle by one of the three clans from Lamotrek.

In these oral histories, narratives of all three chiefly clans indicate their original homeland to be Yarawo, and tell of their ancestors coming via the western islands; Yap, Woleai, Ifalik, or Lamotrek. On the other hand, the histories of the five commoner clans, including Sawsát, claim that their ancestors migrated from the eastern islands: Truk, Puluwat, Tamatam, or Pulusuk. According to an oral history of Pulap Atoll the chief of the autochthonous clan of the island passed his authority to his son whose mother came from Yap (Flinn 1982:62; Komatsu 1990:29-30). Thus chieftainship is legitimized by the "fact" that the principal ancestress of the chiefly clan is descended from Yap. Also in Ulul chieftainship was transferred from father (chief) to a son whose mother came from Faraurep Atoll located to the west of Ulul Island (Sudo 1977:212; Thomas 1978:53, 85). In the remainder of the paper I will examine this association of migration routes and rank based on oppositions: first occupant/stranger, western/eastern, chiefly/commoner, in the context of the social and political organization of the central Caroline Islands.

\section{Two Legendary Homelands of the Caroline Islanders}

In the oral history of Truk and Pohnpei, an island called Kachaw or Achaw is described as the place from which clan ancestors are said to have come, some as high-ranking immigrants (Goodenough 1986:552-553; Mauricio 1987:63; Sudo 1985:838-844). The Trukese and other central Carolinians identify Kachaw with Kosrae Island, situated between Pohnpei and the Marshall Islands. Some chiefly clans validate their superiority by emphasizing their derivation from ancestral immigrants from Kachaw.

On the other hand, in the oral history of the islands closer to Yap in the central Carolines, Yap is considered to be the ancestral homeland. Thus, the mythical "great ghost" of Ulithi Atoll is said to have come from Yap (Lessa 1976:64-65, 1980:48-53). According to the traditions of Ifalik Atoll, the first settlers are said to have comprised a colony from Yap (Burrows and Spiro 1957:7; Alkire 1984:3-4). A narrative collected by Burrows illustrates this connection (Burrows and Spiro 1957:7):

Long, long ago, a chief of Garpar (Gatshapar) village, in the Gagil district, Yap, ordered some of his people to go out and colonize the outer islands to the east. He himself remained in Yap.

In charge of the expedition was a man named Tatar who was accompanied by his sister, Iau. They went first to Mogmog on Ulithi, then to Wetegau (Utagal?) in Woleai, then to Ifalik and the other islands - Faraulep, Elato, Lamotrek, Satawal, and so on to Puluwat and Truk and "all Caroline 
place." The chain of command, ever since, is from Yap to Mogmog, from Mogmog to Wetegau, Wetegau to Ifaluk, from Ifaluk to the other islands.

On Ifalik, Tatar left one man and one woman from each of the eight clans. The two from each clan were brother and sister. Their names were

From Kovalu clan: Maraige and his sister Lemaregara.

From Sauvelarik clan: Alovar and his sister Eilapikel.

From Mangaulevar clan: Trigabwa and his sister Ungusaren ...

The descendants of these women, who married the men from other clans, make up the membership of the clans today.

This tradition attributes the first settlement of Ifalik to immigration from Yap and explains the origin of the political order that exists between Yap and the other islands. It indicates also the present-day relationship among the eight clans of Satawal.

In another Ifalik oral history from Burrows (1963:72-77), Ifalik warriors attacked and killed the original inhabitants of the neighbouring islands of Woleai and Lamotrek. They then repopulated the islands and men from Ifalik became the chiefs in Woleai and Lamotrek. The tale of the "Ifalik conquerors" is popular in the oral history of the central Carolines. I collected the same kind of tale on Satawal. The original story of the Mongonufarh clan mentioned above is connected with this tale. These oral histories all assert that the first of the new settlers carried the title of chieftainship to each island and that the ancestors of the chiefly clans migrated from the west, ultimately coming from Yap.

\section{Political Relationship Between Yap and the Outer Islands}

The societies of the twenty-four coral islands between Yap and Truk were tied to Yap in a supra-island political system. These islands were obliged to send tribute once a year to the Gagil district of Yap until early in this century. This system of tribute, called sawei, defined the "Yap Empire" (Lessa 1950:42). Similar ties existed between the various groupings of outer islands: Woleal, Lamotrek-Satawal-Elato and Puluwat-Pulap-Pulusuk (Alkire 1965:145-149, 1978:119; Flinn 1982:35).

\section{Sawei: Politico-religious tribute system}

Yap domination linked the outer islands to one another in a single political system. In general, rank decreased with distance from Yap. Orders for tribute were sent out from Yap through a chain of authority from the highest to the lowest ranking island, beginning with Mogmog on Ulithi and ending with the easternmost of the outer islands. As the lowest in rank, the people of Namonuito Atoll were annually the first to embark on the reverse tribute voyages toward 
Yap. Tribute goods moved from lower to higher ranking islands until they reached the Gagil district (Figure 1).

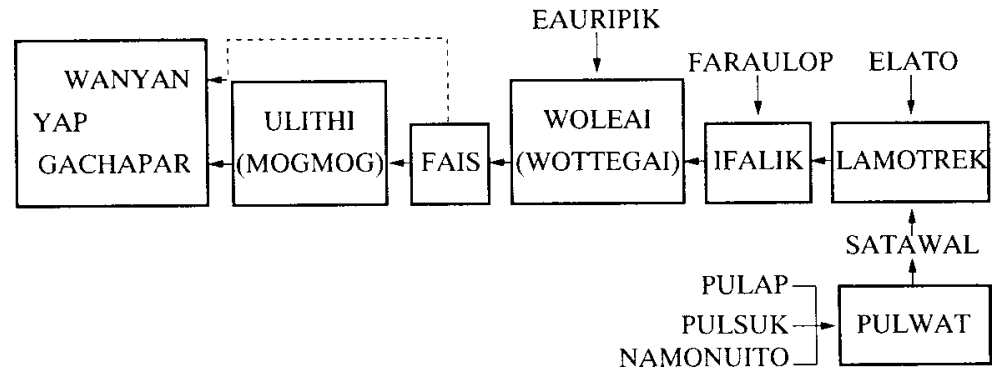

Figure 1. The flow of the tributes (Ushijima 1987).

Representatives of each of the islands carried three categories of gifts, which were "Canoe Tribute", "Religious Tribute", and "Tribute of the Land" (Alkire 1970:5-6). Canoe Tribute and Religious Tribute usually consisted of woven fibre cloth, pandanus mats and coconut oil. They were handed to the chief of Gachapar by the highest ranking island chief, the paramount chief of Ulithi. Canoe Tribute was passed into the hands of the ranking chiefs of Gachapar and Wanyan villages in the Gagil district. Religious Tribute consisted of offerings to the mythical Yapese founder of the sawei, Yangolap, who was enshrined on the estate of the chief of Gachapar.

On the other hand, Tribute of the Land was kept by the representatives of the outer islands and given to their respective sawei partners on Gagil, whose estates held title to particular plots of land on their islands (Alkire 1970:6; 1980:232; Ushijima 1987:304). This tribute included woven cloth, mats, sennit rope, coconut oil and various kinds of shell. When the outer island people returned to their own islands, their Yapese partners provided them with a number of gifts, including turmeric, yams, bananas, sweet potatoes, bamboo, red soil pigment, pots, and manufactured items which were scarce in the outer islands.

The ideology of sawei maintained that the estates of Gachapar and Wanyan villages in the Gagil district held suzerainty over specific outer islands or districts of these islands. Therefore the sawei relationship was one of landlord and serf (Lessa 1950:32, 1966:36-39). The superior status of the Yapese over the outer island people was also described in the idiom of a fictive "parent-child" relationship. As "children", the outer island people were obligated to send tribute to the people of Gagil (Lingenfelter 1975:147). In return they were given food and shelter in Gagil whenever they visited Yap. However, they were considered low caste, with the same rank as the lowest ranking members of Yapese society. They were therefore expected to show deference and were prohibited from marrying Yapese (Lessa 1950:144; Ushijima 1987:305). 
If tribute was not sent, a Yapese chief or magician might cause storms or epidemics to decimate the offending kin group or to destroy the island which had failed in its obligations. Canoe voyages over long distances were prohibited by the Japanese government in the 1920s so that this system no longer operates. However, on the outer islands, aged men still hold a deferential attitude toward the Yapese and fear Yapese sorcery. The Satawalese people still rely on traditional knowledge of weather-forecasting based on the rising and setting of particular stars and constellations to predict the periodic storms which strike the island each year from the northeast or east (Akimichi 1980:16-29). On the other hand they cannot foretell by such traditional methods the tropical storms and typhoons that strike the island from the west. These, which sometimes cause severe damage, are thought to be caused by Yapese magicians or sorcery.

Although oral traditions of Ifalik suggest that the Yapese invaded the outer islands, there is little archaeological or linguistic evidence to support these narratives. Linguistically the central Carolinian languages belong to Nuclear Micronesian and are grouped with Trukic (Bender 1971:438; Goodenough and Sugita 1980:xii; Tryon 1984:157). The affiliation of Yapese is still unclear. According to archaeological evidence the occupation of Fefan on Truk began by 2000 BP (Shutler, Sinoto and Takayama 1984:60) while Yap was occupied as early as 176 AD (Gifford and Gifford 1959:200). Although archaeological excavations in the central Caroline Islands are still few, they indicate that Lamotrek island was inhabited by $1000 \mathrm{AD}$ and possibly as early as $300 \mathrm{AD}$ (Fujimura and Alkire 1984:125).

In addition Yap is culturally and physically distinct from the central Caroline Islands (Bellwood 1978:285). The central Carolinians from Woleai to Namonuito share some clan names, a similar socio-political organization, traditional belief systems, and many features of material culture with Truk. The people of these islands also made canoe voyages to Truk every two or three years where until the 1960s they exchanged products and turmeric and maintained reciprocal relationships with the Trukese. They were thus able to obtain all their necessities, which were not produced in their island, from Truk, without going all the way to Yap. The central Carolinians were migrants voyaging from Truk, not from Yap (Alkire 1984:3-4). For the outer islanders, sawei or tribute and deference paid to Yapese seems to have been based on fear of Yapese sorcery.

\section{Sayiniké: Political ties of Lamotrek and Satawal}

A smaller system of tribute and exchange persisted in the Lamotrek-Satawal-Elato Islands until the 1950s. Lamotrek was ranked politically above Satawal and Elato. The relationship between the three islands was called ké or "fish hook", because Lamotrek politically controlled the other two islands (Alkire 1965:145-149). 
Satawal and Elato Islands were obliged to send semi-annual tribute to Lamotrek. The chiefs of Satawal required each homestead to contribute one basket of preserved breadfruit and hundreds of coconuts. These foods were sent to Lamotrek by sailing canoes. This tribute voyage was called sayinike or the "voyage of the fish hook". The paramount chief of Lamotrek received this tribute and offered some of it to his ancestress. The rest was distributed to all the homesteads on the island. Lamotrek was not required to return anything as a counter-gift because this tribute was recognized as a token payment in return for which Satawal was allowed to exploit the nearby uninhabited islands controlled by Lamotrek. On the other hand, Satawalese people considered these prestations as offerings to their ancestress, from whom the ancestress of the chief of Satawal descended. When Satawal was hit by storms or typhoons and there was a scarcity of food, the chief of Satawal could ask for assistance of taro or coconuts from the chief of Lamotrek.

These tribute systems of sawei and sayiniké can be interpreted as exchange systems involving "mutual assistance in the form of subsistence" between the high island of Yap and low islands, or between the outer islands and the neighbouring coral islands. On the other hand this system was maintained both politically and religiously by a lineal chain of authority based on a tradition of priority of settlement or resettlement (irrespective of what can be established as the actual historical order of settlement). The important point to emphasize is that the oral history of Satawal, Pulap, Ulul and Ifalik portray the chiefly clans of the outer islands as having migrated from the west; i.e. from Yap, Woleai, Ifalik or Lamotrek, in accordance with the hierarchy as formed by tribute relations.

\section{Clan and Land}

Land is another important element in the status system. In Truk and the central Caroline Islands generally it is argued that clan ranking is determined not only by order of settlement but also by the amount of land originally controlled by each clan (Goodenough 1951; Alkire 1970; Nason 1970; Shimizu 1987). This principle of determining clan rank is common in Satawalese society (Sudo 1984, 1987).

On Satawal, however, it is not the first-settlers but the first of the new settlers whose descendants comprise the chiefly clans of the island. According to oral traditions, Sawsát, the original clan, passed its proprietary right to the island's land and to its chieftainship to the Neyáar clan, which was the first of the new settlers to arrive after Sawsát. After this transfer the Neyáár people owned the entire island by the right of being the first settlers from a "high ranking island", Lamotrek, and the Sawsát clan became subordinate to Neyáár. When the other two chiefly groups migrated from Lamotrek, the Neyáár clan gave large amounts of land to them and divided the island into three villages: the south, middle and 
north. By this division, control of the south village was retained by the Neyáar clan, while the middle and north were granted to the Noosomwar and Yáanatiw clans, respectively.

As the other clans migrated to Satawal, they were, in turn, given several plots of land by one or the other of these three clans, depending on where they settled. Maasané, for instance, is said to have come under the patronage of the Neyáár clan and to have settled near the Neyáár homestead, receiving Neyáár land in the process. The relationship between land-giver and land-receiver is called yakkune, which means "to be trustworthy to each other". Land-receivers are linked in a subordinate relationship to land-givers, and are obliged to follow the directives of the latter when requested. The three land-giving clans, Neyáar, Yáánatiw, and Noosomwar, held the highest rank and were known as "chiefly" clans. On the other hand, the four land-receiving clans, Kataman, Piik, Sawen, and Maasané, were subordinate and called "commoner" clans. Though not a land-receiver, the Sawsát clan was, as we have noted, also considered a commoner clan.

The three chiefly clans still own large tracts of land on Satawal. The amount of land that is currently controlled by each of the eight clans is shown in Table 1. The clans of the first settlers from Lamotrek established priority of land control and continue to own the largest amounts of land. Thus arrival sequence of land-ownership is a close reflection of clan rank.

\section{Conclusions}

In this paper I have examined the characteristics of chieftainship and the principal elements determining rank and status among kin groups in the central Carolines.

There are two contrasting principles of precedence operating here:

- $\quad$ one based on priority of settlement, referring to migration legends tracing homelands to an eastern island, Kachaw (Kosrae); and

- another based on inter-island tribute and economic relations, connecting to western islands, ultimately to Yap. 
Origins, Ancestry and Alliance

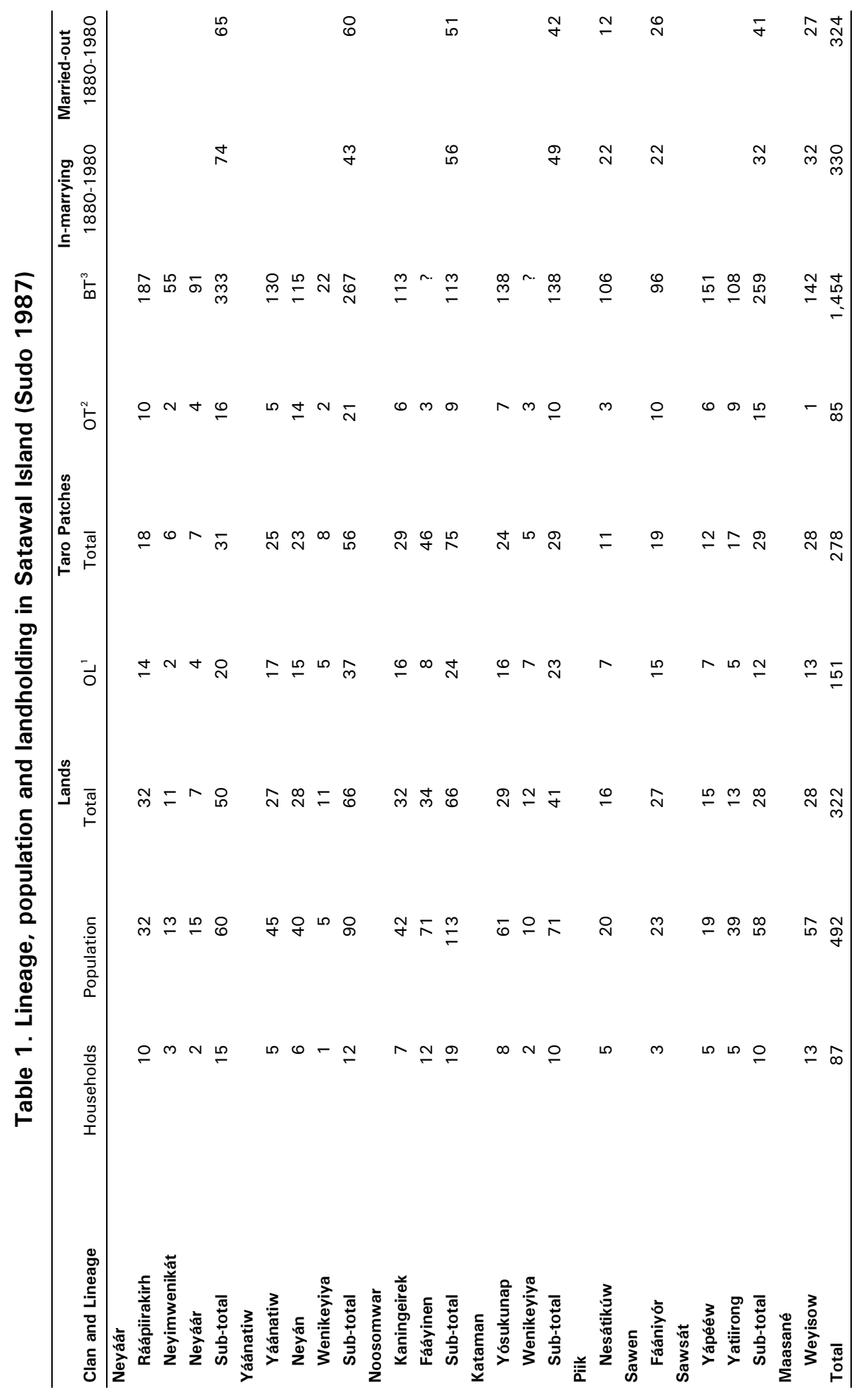


Notes: ${ }^{1}$ OL: original land; ${ }^{2}$ OT: original taro patches; ${ }^{3}$ BT: Breadfruit tree.

The first principle is a basic and general element used to legitimize chieftainship. The second principle operates in the acquisition of chieftainship and its maintenance in some island societies - Satawal, Ulul, Pulap - where the chiefly clan became extinct or where chieftainship was usurped by another clan. In this new political order, settlers from western high ranking islands carry the title of chief. Regardless of the actual historical order of settlement, the highest ranking clans articulate their oral history of migration to assert their legitimacy of the chieftainship by claiming as their homeland two centres of influence: Kachaw and Yap.

Another element that validates chieftainship is land-ownership. This is demonstrated not only by the fact that the highest ranking chiefly clan holds the largest amount of land on the island, but also by oral history in which this clan is represented as having originally controlled all of the land of the island. In other words, the first settlers assumed a dominant status as the primary title holders to the entire territory of the island and later settlers were given a subordinate status as secondary title holders. It is a characteristic feature of chieftainship in the Carolines that the most important responsibility of the chief is to manage food resources while maintaining the social order. Thus the superior/inferior relationships are expressed symbolically through gifts of "first crops".

\section{References}

Akimichi, Tomoya

1980 Storm star and ethnometeorology on Satawal. Kikan Zinruigaku 11:3-15 (in Japanese).

Alkire, William H.

1965 Lamotrek Atoll inter-island socioeconomic ties. Illinois Studies in Anthropology No. 5. Urbana: University of Illinois Press.

1970 Systems of measurement on Woleai Atoll, Caroline Islands. Anthropos 65:1-73.

1978 Coral islanders. Arlington Heights, IL: AHM Publishing Corp.

1980 Technical knowledge and the evolution of political systems in the central Caroline and Western Islands of Micronesia. Canadian Journal of Anthropology 1:229-237.

1984 Central Carolinian oral narratives: indigenous migration theories and principles of order and rank. Pacific Studies 7:1-14.

Bellwood, Peter 
1978 Man's conquest of the Pacific: the prehistory of Southeast Asia and Oceania. London: Collins.

Bender, Byron W.

1971 Micronesian languages. In T.A. Sebeok (ed.) Linguistics in Oceania, 2 vols. Current Trends in Linguistics, vol. 8, pp.426-465. The Hague: Mouton.

Burrows, Edwin G.

1963 Flower in my ear: arts and ethos of Ifaluk atoll. Seattle: University of Washington Press.

Burrows, Edwin G. and Melford E. Spiro

1957 An atoll culture: ethnography of Ifaluk in the Central Carolines. New Haven: Human Relations Area Files Press.

Flinn, Juliana B.

1982 Migration and inter-island ties: a case study of Pulap, Caroline Islands. $\mathrm{PhD}$ dissertation, Stanford University.

Fujimura, Keiko and William H. Alkire

1984 Archaeological test excavations on Farauiep, Woleai, and Lamotrek in the Caroline Islands of Micronesia. In Yosihiko H. Sinoto (ed.) Caroline Islands archaeology: investigations on Fefan, Faraulep, Woleai, and Lamotrek. Pacific Anthropological Records No. 5, pp.66-129. Honolulu: B.P. Bishop Museum.

Gifford, Edward W. and Delia S. Gifford

1959 Archaeological excavations in Yap. Anthropological Records 18(2):149224.

Goodenough, Ward H.

1951 Property, kin, and community on Truk. Yale University Publications in Anthropology No. 46. New Haven: Yale University Press. [Reprinted 1978, 2nd ed. Hamden, CT: Archon Books.]

1986 Sky world and this world: the place of Kachaw in Micronesian cosmology. American Anthropologist 88:551-568.

Goodenough, Ward H. and Hiroshi Sugita

1980 Trukese-English dictionary. Philadelphia: American Philosophical Society. Komatsu, Kazuhiko

1990 A sketch of chieftainship on Pulap: island community and its 'exterior'. In Iwao Ushijima (ed.) Anthropological research on the atoll cultures of 
Micronesia, 1988, pp.21-34. Tsukuba: Department of Anthropology, University of Tsukuba.

Lessa, William A.

1950 Ulithi and the outer native world. American Anthropologist 52:27-52.

1966 Ulithi: A Micronesian design for living. New York: Holt, Rinehart, and Winston.

1976 The apotheosis of Marespa. In Adrienne L. Kaeppler and H. Arlo Nimmo (eds) Directions in Pacific traditional literature: essays in honor of Katharine Luomala. Bernice P. Bishop Museum Special Publications No. 62, pp.6181. Honolulu: Bishop Museum Press.

1980 More tales from Ulithi atoll: a content analysis. Folklore and Mythology Studies No. 32. Berkeley: University of California Press.

Lingenfelter, Sherwood G.

1975 Yap: political leadership and culture change in an island society. Honolulu: University Press of Hawaii.

Mason, Leonard

1968 Suprafamilial authority and economic process in Micronesian atolls. In A.P. Vayda (ed.) Peoples and cultures of the Pacific: an anthropological reader, pp.299-329. New York: Natural History Press.

Mauricio, Rufino

1987 Peopling of Pohnpei Island: migration, dispersal and settlement themes in clan narratives. Man and Culture in Oceania 3:47-72.

Nason, James D.

1970 Clan and copra: modernization of Etal Island, Eastern Caroline Islands. PhD dissertation, University of Washington.

Shimizu, Akitoshi

1987 Chieftainship in Micronesia. Man and Culture in Oceania 3 (special issue):239-252.

Shutler, Richard, Jr, Yosihiko H. Sinoto and Jun Takayama

1984 Preliminary excavations of Fefan Island site, Truk Islands. In Yosihiko H. Sinoto (ed.) Caroline Islands archaeology: investigations on Fefan, Faraulep, Woleai, and Lamotrek. Pacific Anthropological Records No. 5, pp.1-64. Honolulu: B.P. Bishop Museum.

Sudo, Ken-ichi

1977 Field notes on an outer island life, Ulul Island of Truk. Annual Journal of Social Anthropology, 202-220 (in Japanese). 
1984 Systems of land tenure and resource management on Satawal Island, Micronesia. Bulletin of the National Museum of Ethnology 10:197-348 (in Japanese).

1985 Structural change in matrilineal descent group in Greater Trukese societies. Bulletin of the National Museum of Ethnology 10:827-926 (in Japanese).

1987 Land tenure and social organization in Micronesia. Man and Culture in Oceania, 3 (special issue):253-266.

1989 Matrilineal structure in island societies, Micronesia. Tokyo: Kinokuniya Shoten (in Japanese).

Thomas, John B.

1978 Adoption, filiation, and matrilineal descent on Namonuito Atoll, Caroline Islands. PhD dissertation, University of Hawaii.

Tryon, D.T.

1984 The peopling of the Pacific. Journal of Pacific History 19:147-159.

Ushijima, Iwao

1987 Society and exchange on Yap. Tokyo: Kobundo (in Japanese). 